THURSDAY, MARCH 26, 1903.

\section{ANCIENT ASTRONOMY.}

Sphaera; neue griechische Texte und Untersuchungen zur Geschichte der Sternbilder. Von Franz Boll. Pp. xii +564 ; with illustrations and 6 plates. (Leipzig : Teubner, 1903.) Price 24 marks.

THIS is undoubtedly one of the most important works 1 on the history of astronomy that has appeared for many years. The author here publishes and annotates the text of several newly discovered manuscripts of astronomical-astrological authors of the Classical and Byzantine periods. The names of Teukros the Babylonian, Antiochos, Valens, and the poet Johannes Kamateros were known to us before, but Herr Boll has considerably increased our knowledge of them and their work, and he has, indeed, almost added a new chapter to the history of astronomy.

The first part of Herr Boll's work deals with the critical discussion of the new texts, the second with the description of the constellations mentioned in them, the third with the history of the "Sphaera Barbarica" in reference to the work of Nigidius and others. The third part closes with a sketch of the history of mediæval and modern astronomy. To the appendix Herr Karl Dyroff has contributed a most useful edition and translation of part of the "Book of the Great Introduction" (Kitab al-mudhal $a l$-kabîr) of the Arab astronomer of Irak, Abu Ma'sar Ja'far ibn Muhammad al-Balbî.

Naturally the greater part of the book is taken up with a description of the constellations of the Greek and Egyptian Heavens as given by Teukros and the rest. This leads Herr Boll to deal with many extremely interesting questions in the course of his annotations on the words of his authorities. The section on the Egyptian "Sphaera" is extremely good, and we must congratulate a "nichtägyptolog" upon the general accuracy of his critiques of Egyptological and other theories of Egyptian astronomy. Nevertheless, a few references ought to have been made by the author to other authorities besides those who have written in German and French. He seems unacquainted, as far as we can see, with works in English which deal with the subject. Yet there are several of weight and authority, notably Sir Norman Lockyer's "Dawn of Astronomy."

New light is thrown by this author on the question of the origin of the representations on the Græco-Egyptian zodiacs at Dendera and Esna. He shows that the Egyptian element in them is really greater than has often been supposed, and at the same time notes the probable origin of the non-Egyptian constellation-figures, \&c., of which the majority are, as in the case with the Greek "Sphæra," of Babylonian origin, such as the Goat-Fish, the Scorpion, the Centaur, \&:. The signs of the zodiac are all of Babylonian origin, as Jensen showed several years ago in his useful book, "Die Kosmologie der Babylonier."

Herr Boll further shows that the purely Egyptian figures in these zodiacs and in more ancient astronomical representations in the tombs of the Bibân al-Mulûk and elsewhere are really intended to represent constellations, and not single stars, as Letronne and Ideler thought. $\mathrm{He}$ gives interesting parallel plates of the Zodiac of Dendera from a photograph of a cast and from the old picture in the "Expédition de l'Égypte," which is by no means incorrect, as may be seen on comparison with the photograph. Further, on p. 20r, he gives an illustration of a circular zodiac or planisphere from a Babylonian boundary-stone of about I 100 B.C. ; an important monument in the history of astronomy.

How the Egyptians regarded the stars is shown by the author with the aid of a quotation from Prof. Maspero's "Revue de l'Histoire des Religions":-

"Die ägyptische Anschauung sah überhaupt in den Sternen Leuchten. 'Les astres ne son: pas pour les Égyptiens des corps célestes; ce sont des lampes (khabisou) allumés au firmament. Les Égyptiens conçevaient les dieux-étoiles comme certains pères de l'Église considéraient les anges chargés d'entretenir les astres: c'étaient des dieux lampadophores. Au Tombeau de Séti I I Isis-Sothis porte sa lampe sous forme d'étoile à cinq branches au-dessus de sa coiffure et Osiris-Orion la sienne au-dessus de son sceptre.' Ganz besonders aber war nach Brugsch der Name Lampe oder Leuchten ( $\chi$ ebs, lucerna) den Dekansternen eigen. Auf den beiden Tierkreisen von Esne sind tierischmenschliche Gestalten mit Sperber-oder Hunds- oder Widder-köpfen zu sehen, die auf vorgestreckten Händen kleine Lampen tragen: 'dieux lampado-

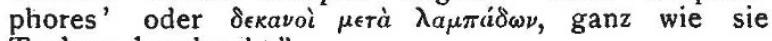
Teukros beschreibt."

In dealing with the text of the newly discovered authorities and collating them with one another, Herr Boll has often been led to make interesting comparisons and connections. In describing the Ram and the Bull, Antiochos speaks of a constellation called "The Syrian Horse," $\delta$ sípıos immos. Valens, in describing the Bull,

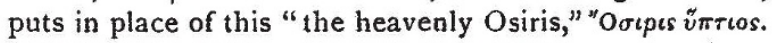

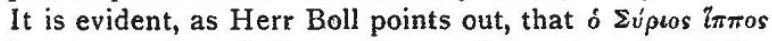

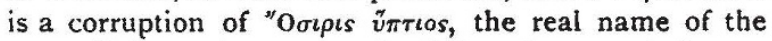
constellation. As a corruption it is rather a curiosity.

Herr Boll has omitted to note, in speaking of the constellation Typhon (the Great Bear), that this name is purely Greek, and would have been unintelligible to an Egyptian; he uses it as if he thought it were the Egyptian name. The Egyptologists are to blame for this, and we wish they would banish this "Typhon,' identifications of Hathor with "Venus," and talk about "Jupiter" Ammon from their works. The Egyptian name for the Great Bear or Plough is the "Thigh of Set." the Ahriman of Egyptian religion, who was identified by the Greeks with their giant Typhaon or Typhon, son of Typhoeus and grandson of Tartaros. Ordinarily the constellation was called "the Thigh," and a very good name it is too, almost as good as our "Plough," and much better than "Charles's Wain" or the "Great Bear." The form is iust that of the thigh of an animal.

Altogether this book will be found very interesting by all astronomers who are interested in the past history of their science, and very useful to the Hellenist, the Egyptologist and cuneiform scholar, who will find (with the English exceptions already noted) the latest results of both astronomical and archæological researches bearing upon the subject of the astronomy of the ancients. 